\title{
Retaining High Achievers in Times of Demographic Change. The Effects of Proactivity, Career Satisfaction and Job Embeddedness on Voluntary Turnover
}

\author{
Jutta Lang, Marcel Kern, Dieter Zapf \\ Department Work and Organizational Psychology, Institute of Psychology, Goethe University, Frankfurt, Germany \\ Email:julamuc@gmail.com
}

How to cite this paper: Lang, J., Kern, M., \& Zapf, D. (2016). Retaining High Achievers in Times of Demographic Change. The Effects of Proactivity, Career Satisfaction and Job Embeddedness on Voluntary Turnover. Psychology, 7, 1545-1561. http://dx.doi.org/10.4236/psych.2016.713150

Received: September 5, 2016

Accepted: November 8, 2016

Published: November 11, 2016

Copyright $\odot 2016$ by authors and Scientific Research Publishing Inc. This work is licensed under the Creative Commons Attribution International License (CC BY 4.0).

http://creativecommons.org/licenses/by/4.0/ (c) (i) Open Access

\begin{abstract}
The present study analyses the specific impact of proactivity, career satisfaction and job embeddedness on career turnover and aims to contribute to the improvement of future recruitment and retention policies. We propose an integrated model that focuses on direct and indirect effects of proactivity, career satisfaction and job embeddedness, on alternative job opportunities, going to job interviews and signing a new job contract. To test our hypotheses we used structural equation modeling with data from 192 employed participants, contacted at two separate points in time, once asking for personality and career related data, and six month later for turnover outcomes. The results support the assumption that proactive but not career satisfied and embedded employees carry with them a higher risk of leaving for greener pastures through their easier access to alternative job opportunities. On their way up the career ladder only high levels of job embeddedness and in particular attractive career opportunities within the present organization make staying more attractive than leaving.
\end{abstract}

\section{Keywords}

Proactivity, Career Satisfaction, Job Embeddedness, Job Opportunities, Voluntary Turnover

\section{Introduction}

There is common consent in the business world that talented people are critical to the success of any organization. The human resource management (HRM) literature sup- 
ports this reasoning and provides broad empirical evidence that knowledge, skills, creativity, innovativeness and other human capital components are key factors to gain sustainable competitive advantage in business (Michaels, Handfield-Jones, \& Axelrod, 2001; Ng, Eby, Sorensen, \& Feldman, 2005). In the context of increasingly uncertain and interdependent work environments, a growing body of HRM research focuses on the impact of proactive employees (Grant \& Ashford, 2008; Seibert, Kraimer, \& Crant, 2001; Parker, Williams, \& Turner, 2006). Theoretical and empirical studies confirm that especially proactivity, defined as a relatively stable personality trait that captures employees' tendencies to enact changes, predicts a variety of relevant beneficial individual behaviours and organizational outcomes (Bateman \& Crant, 1993; Grant \& Ashford, 2008). Beyond the Big Five, proactive personality positively relates to organizational performance indicators, career success, change-oriented citizenship and entrepreneurial performance (Fuller \& Marler, 2009; Griffin, Parker, \& Mason, 2010; Tornau \& Frese, 2013).

Due to the well documented costs associated with an organization's high voluntary turnover rate (Glebbeek \& Bax, 2004) and with regard to the change-oriented nature of proactive employees (Bateman \& Crant, 1993), scholars have begun to examine the relationship between proactivity and staying or leaving preferences (Grant \& Ashford, 2008). On the one hand, they support the idea that proactivity is not synonymous with quitting (Morgan, Walker, Wang, \& Aven Jr., 2012; Seibert et al., 2001). On the other hand, they offer empirical evidence for the supposition that proactive professionals tend to voluntarily change their job more often (Boudreau, Boswell, Judge, \& Bretz, 2001). Even though research has uncovered an extensive amount of diverse individual, organizational and situational predictors and mediators of voluntary turnover, there is still a lack of unambiguous conclusions on proactivity (Holtom, Mitchell, Lee, \& Eberly, 2008). In an effort to further our understanding of how proactivity may affect voluntary turnover, we propose a study approach integrating proactivity into a broader theoretical framework. By utilizing three additional factors commonly found in a number of turnover models, we will shift the focus from former single research designs to a more complex view of the proactivity-voluntary turnover process (Swider, Boswell, \& Zimmerman, 2011).

In order to do so, we refer to the seminal work of March and Simon (1958) introducing a two-factor model of employee turnover. The interest to find a more desirable employment situation is seen as an essential predictor and the ease of movement as potential mediator of voluntary turnover (Griffeth, Hom, \& Gaertner, 2000; Holtom et al., 2008). Perceived desirability is often operationalized by career satisfaction (Boudreau et al., 2001), whereas the ease of movement is measured by means of perceived job alternatives (March \& Simon, 1958). But not each alternative does imply that a new job contract is finally signed (Swider et al., 2011). Even if people decide to evaluate the attractiveness of job alternatives and accept the invitation to a job interview, staying or leaving remain options (Rynes \& Cable, 2003). Mitchell et al. (2001) therefore evolved March and Simon's (1958) model into a three-factor model. Based on field theory 
(Lewin, 1951), they developed the job embeddedness concept that identifies organizational and community-related network-forces as main drivers in employees' turnover considerations. Job embeddedness predicts the key outcomes of both intent to leave and voluntary turnover (Crossley, Bennett, Jex, \& Burnfield, 2007).

To capture the specific value added by proactivity to predict voluntary turnover, we integrate the prevalent concepts of career satisfaction, job embeddedness and perceived job alternatives in our study design. We first analyze effects of proactivity, career satisfaction and job embeddedness on perceived job opportunities and going to job interviews. Second, we examine the relationship between job opportunities, going to job interviews and signing a new job contract. Third, we analyze possible mediating effects of job opportunities and job interviews on the relationship between proactivity, career satisfaction and job embeddedness on the one hand and voluntary turnover on the other. Finally, we test if turnover rates can be fully explained by getting job opportunities and going to interviews.

\subsection{Proactive Personality}

In recent years, scholars have identified a lot of beneficial effects of proactivity at work. Research suggests that proactivity, a strong predictor of personal initiative (Frese \& Fay, 2001), voice (Van Dyne \& LePine, 1998) and taking charge behavior (Morrison \& Phelps, 1999), also stands for the core orientation to change situations instead of waiting for changes (Tornau \& Frese, 2013). Thus, one might expect a pronounced willingness of proactive persons to look for greener pastures elsewhere when their vocational circumstances do not meet their needs (Allen, Weeks, \& Moffitt, 2005). However, previous research on proactivity and voluntary turnover offers mixed results: sometimes reporting lower intentions to leave for individuals who score higher in proactive personality and career commitment (Morgan et al., 2012) and on the other hand supporting the idea that proactivity, a most wanted personality asset in the labour market, will enhance the chance to receive alternative job offers, a necessary prerequisite of turnover (Boudreau et al., 2001). In order to get abetter understanding on how exactly proactivity affects voluntary turnover we will consider March and Simon's (1958) model of turnover and analyze in a first step the relationship between proactivity and perceived job alternatives. Recent studies on employment opportunities support the idea that professionals with higher levels of work performance receive more often external job offers than average or low performers (Glebbeek \& Bax, 2004). Moreover, guidelines on best practice in HRM highly recommend to focus recruitment strategies on changeoriented, proactive candidates (Fuller \& Marler, 2009). Scholars analyzing job conditions for talented people suggest that proactivity, an attitude strongly related to career success and extra-role performance, may facilitate the access to employment opportunities (Seibert et al., 2001). Thus, we posit the following:

Hypothesis 1a: There is a positive relationship between proactivity $(t 1)$ and the probability to receive job opportunities six months later ( $t 2)$.

Previous research has often demonstrated that proactive people identify opportuni- 
ties and act on them (Seibert et al., 2001). As proactive individuals will actively attempt to promote their career, one can assume that they not only receive more attractive job opportunities. Also, they will be more interested to gain substantial knowledge about their own marketability and tend to have interviews with potential future employers (Briscoe, Hall, \& DeMuth, 2006). One might therefore suggest that proactivity, independently from other factors, also directly affects the tendency of accepting invitations to job interviews:

Hypothesis $1 b$ : There is a positive relationship between proactivity $(t 1)$ and the probability of participating in job interviews six months later $(t 2)$.

\subsection{Career Satisfaction}

For decades, research on voluntary turnover found robust support that not only job alternatives, but also career dissatisfaction are strong predictors for quitting one's job (Holtom et al., 2008; March \& Simon, 1958). Career satisfaction is widely used as an indicator for the subjective perception and evaluation of one's career progression and success (Dormann \& Zapf, 2001). Employees with feelings of uncertainty about future career steps are more willing to really test other career options (Posthuma, Maertz, \& Dworkin, 2007). Career dissatisfaction encourages individuals to search actively for new employment opportunities (Ng et al., 2005). The probability to receive employment opportunities depends directly on the intensity of previous job search (Griffeth et al., 2000; Holtom et al., 2008). Career unsatisfied people are more engaged in active job search behavior and will more often accept invitations to job interviews (Griffeth et al., 2000). Therefore, we propose the following hypotheses:

Hypothesis 2a: There is a negative relationship between career satisfaction ( $t 1)$ and the probability to receive job opportunities six months later $(t 2)$.

Hypothesis $2 b$ : There is a negative relationship between career satisfaction $(t 1)$ and the probability of participating in job interviews six months later ( $t 2)$.

\subsection{Job Embeddedness}

Research on the effects of job embeddedness on voluntary turnover turned the question from why do people leave to why do they stay (Mitchell et al., 2001). The job embeddedness construct conceptualizes on- and off-the-job forces and their binding power. The composite measure includes links, fits and sacrifices employees face in their work and non-work environment. The job embeddedness construct thereby explains unique variance in turnover outcomes besides the traditional models of turnover (Crossley et al., 2007). Strong links, a good fit in the organization and community and high sacrifices upon leaving the organization significantly increase the employee retention. Job embeddedness improves the prediction of voluntary turnover over and above that accounted for by job satisfaction and perceived job alternatives (Mitchell et al., 2001). Based on these research findings it can be expected that employees embedded in their job and community do not search actively for a new job, they therefore receive less often job offers and will avoid the effort and cost needed to go to job interviews. 
Thus we propose the following hypotheses:

Hypothesis 3 a: Employees, embedded in their job and community $(t 1)$ will less often receive job opportunities six months later $(2)$.

Hypothesis $3 b$ : Employees, embedded in their job and community $(t 1)$ will less often go to job interviews with a new employer six months later ( $t 2)$.

\subsection{Job Opportunities}

A recurrent topic in turnover research is that the availability of job opportunities will influence not only turnover intentions but also leaving behavior. Already March and Simon (1958) argued that turnover will more likely take place when labor market conditions are such that alternative jobs are more generally available. Lee and Mitchell (1994) explained in their model of employee turnover, that particular events like administrative changes, firm mergers and also unsolicited job offers will trigger turnover. Alternative job opportunities are seen as positive shock that may induce the development of quit intentions without job dissatisfaction. Recent research supports the idea that people will carefully consider available job opportunities and if it is worthwhile they will change to a more attractive employer (Swider et al., 2011). Based on the above discussion and counting on the popular phrase "an open door may tempt a saint", we suppose a strong link between job opportunities and the decision to follow an invitation for a job interview. Moreover, going to job interviews should enhance the probability to sign a new job contract:

Hypothesis 4a: The availability of alternative job opportunities will increase the probability to go to job interviews.

Hypothesis 4 b: Going to job interviews will increase the probability to sign a new job contract.

\subsection{Indirect Effects}

In this paper, we focus on employed individuals and voluntary turnover. Voluntary turnover occurs when employees quit the organization on their own accord. As there is a widely accepted assumption in the literature that the availability of job opportunities and the invitations to job interviews are logical antecedents in most organizations before signing a new job contract (March \& Simon, 1958, Swider et al., 2011), we will now analyze how the relationship between proactivity, career satisfaction and job embeddedness on the one hand and voluntary turnover on the other is possibly mediated by job opportunities and job interviews.

Empirical results support the positive effects of improving conditions of the labour market particularly for talented people (Cosack, Guthridge, \& Lawson, 2010). Proactivity, an attitude strongly related to job performance (Seibert et al., 2001) may therefore enhance the probability to get a call from a headhunter or recruitment professional with an unsolicited job offer and may serve as a "door opener" for the next steps in a turnover process. Taking into account the sound tendency of proactive individuals to enact changes and to show personal initiative also beyond an actual employment situa- 
tion (Frese \& Fay, 2001) one might also expect that the relationship between proactivity and voluntary turnover is mediated through the higher willingness of proactive employees to accept invitations to job interviews. Thus, we predict the following:

Hypothesis 5: The relationship between proactivity $(t 1)$ and turnover $(t 2)$ is mediated by job opportunities $(t 2)$ and going to job interviews $(t 2)$.

There is broad consensus in turnover research that career satisfaction is a reliable predictor for staying tendencies (Swider et al., 2011). Moreover, a wide range of empirical studies on the attachment construct "job embeddedness" provides further support that employees, "embedded" in their job as a result of various organizational and community-related forces, stay in their organization and do not look for alternative employment opportunities. In accordance with previous turnover research on the mediating effects of perceived job alternatives (March \& Simon, 1958; Holtom et al., 2008), we therefore propose that the relationship between career satisfaction (Ng et al., 2005) and job embeddedness (Mitchell et al., 2001) and voluntary turnover is mediated through the lower propensity of career satisfied and embedded people to search job alternatives and to waste private time on interviewing for not intended job changes:

Hypothesis 6: The relationship between career satisfaction $(t 1)$ and voluntary turnover $(t 2)$ is mediated by job opportunities ( $t 2)$ and going to job interviews ( $t 2)$.

Hypothesis 7: The relationship between job embeddedness $(t 1)$ and voluntary turnover ( $t 2)$ is mediated by job opportunities ( $t 2)$ and going to job interviews $(t 2)$.

The so far preferred turnover models often analyzed direct effects of the independent variables proactivity, career satisfaction and job embeddedness on voluntary turnover (Morgan et al., 2012; Seibert et al., 2001). In the previous sections, we argued that these independent variables have an effect on voluntary turnover via the mediating roles of job opportunities and going to job interviews. Beyond the number of received job opportunities and job interviews, however, there may be more reasons and mechanisms why proactive employees will more often accept a job offer, whereas career satisfied and embedded employees less often sign a new job contract. These additional effects can be analyzed by looking on direct effects of the independent variables on voluntary turnover (see Figure 1, inclusive dotted lines). We, therefore, propose the following:

Hypothesis 8: A model including direct and indirect effects of proactivity, career satisfaction and job embeddedness on voluntary turnover fits better than a model without direct effects.

\section{Method}

\subsection{Sample and Procedure}

The present study was carried out in Germany. More than 2000 individuals were invited via email to participate in an online survey. Email-addresses were collected from different sources like the German Chamber of Commerce and Industry, and other professional networks. Giving "career management" as the subject of our interest and assuring strict confidentiality, the addressees were asked to rate their personal career management strategies. The provided link was opened by 1031 individuals, while 938 


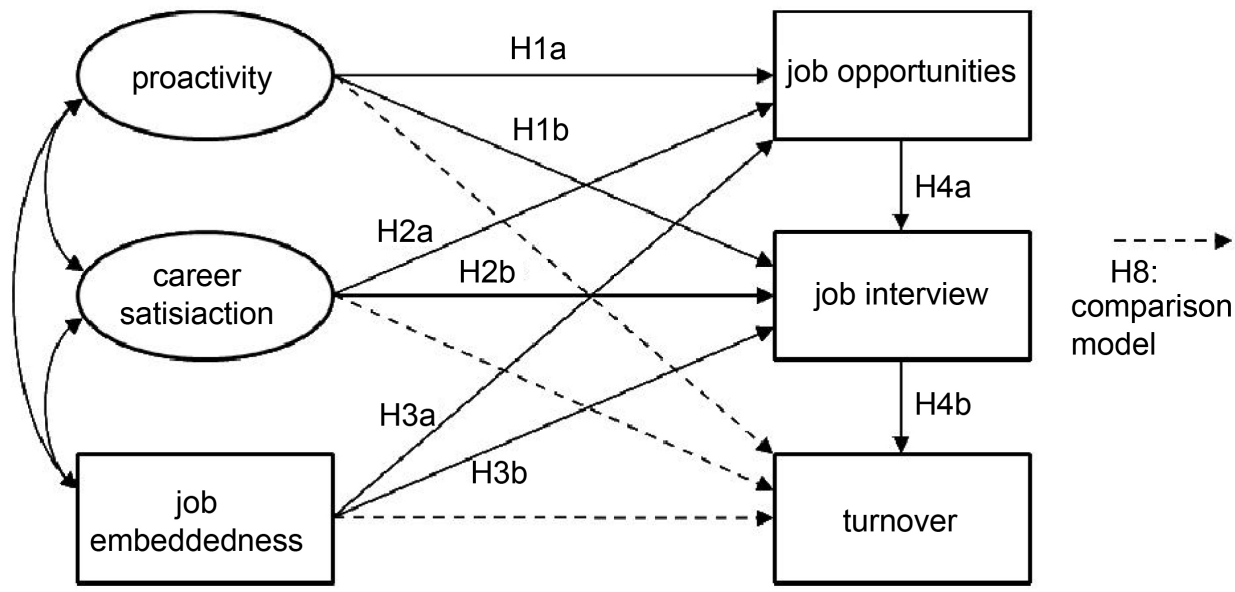

Figure 1. Research model. How proactivity, career satisfaction, job embeddedness and perceived job alternatives may affect turnover. Labels for indirect effects (hypotheses 5 to 7 ) not shown.

persons started the survey and 506 completed it. The returned data were carefully screened and all cases with missing data were removed. Six months later ( $\mathrm{t} 2$ ) a followup survey was sent to the remaining 388 individuals asking for job offers, job interviews and voluntary turnover. 192 follow-up surveys (118 male, 74 female) were completed and returned. At time two 115 respondents had received job offers, 66 had gone to job interviews and 28 had signed a new job contract. The average completion time for the first survey was 20 minutes, and 5 minutes for the follow-up questionnaire.

A series of $t$-tests $(d f=578)$ revealed that time 1 and 2 respondents $(\mathrm{N}=192)$ did not differ significantly $(p>.05)$ from time 1 respondents $(\mathrm{N}=388)$ in terms of gender $(t$ $=.93)$, age $(t=.16)$, academic major $(t=1.37)$, hierarchy level $(t=.00)$, length of employment $(t=.07)$, career satisfaction $(t=.45)$, job embeddedness $(t=.24)$ and proactivity $(t=.47)$. Thus our time 1 and time 2 respondents were representative of our time 1 sample.

\subsection{Measures}

In our online survey all questions were formulated in German. In all cases where no German version of the instrument was available, we employed a translation-backtranslation procedure to translate the items from English into German (Hambleton \& Kanjee, 1995).

Past research has conceptualized proactivity as a relatively stable individual disposition toward proactive behavior (Bateman \& Crant, 1993). Recent research confirms a consistently positive relationship between proactive personality and specific proactive career behaviors in an organizational context (Tornau \& Frese, 2013). To measure Proactivity (t1) we used Bateman and Crant's (1993) 10-item Proactive Personality Scale. Sample items were "I am always looking for new ways of shaping my life", "If I firmly believe in something, I find ways of realizing it regardless of the opportunities", and "I recognize good opportunities long before the others". Responses were made on a 5point Likert-type scale ranging from $1=$ "strongly disagree" to $5=$ "strongly agree". 
Career satisfaction ( $\mathrm{t} 1)$ was assessed at Time 1 via the Career Satisfaction scale (Greenhaus, Parasuraman, \& Wormley, 1990). The scale consists of five items (e.g., "I am satisfied with the success I have achieved in my career") and participants indicated their agreement on a five-point Likert scale ranging from 1 (do not agree at all) to 5 (fully agree). Composite job embeddedness (t1) was measured with the 40 -item measure developed by Mitchell et al. (2001). All facets except community and organizational links used a five-point response scale ( $5=$ strongly agree). The Organization Fit subscale comprised nine items, such as "My coworkers are similar to me". Organizational Links included seven items, such as "How many coworkers are highly dependent on you?". Organization Sacrifice was composed of 10 items, such as "I would sacrifice a lot if I left this job". The five-item Community Fit subscale included items such as "The area where I live offers the leisure activities that I like". Community links were assessed with a six-item subscale composed of items such as "Are you currently married?", "Do you own the home you live in?" and "How many family members live nearby?". The Community Sacrifice subscale was composed of three items, such as "People respect me a lot in my community". Because response options differed across items, all item responses were standardized before being combined into respective scales.

All variables of the time two questionnaire were dichotomous. First, Job Opportunities (t2) was assessed by asking respondents to indicate whether they had received job opportunities ( $1=$ yes, alternative job opportunities). Second, we asked them whether they went to Job Interviews ( $\mathrm{t} 2)$ with a new employer ( 1 = yes, went to job interviews). Finally, Turnover ( $\mathrm{t} 2$ ) was measured by asking whether the participants remained with or had voluntarily quit the organization ( $1=$ yes, signed a new job contract).

\subsection{Statistical Analyses}

To test our hypotheses, we applied structural equation modeling using Mplus (Muthén \& Muthén, 1998-2012). The variables career satisfaction and proactivity were treated as latent variables with parcels as indicators. Problems arising with non-normal distributed variables can be attenuated with item-parceling. Moreover, this method lowers the variable-to-sample-size ratio and constitutes more reliable constructs (Little, Cunningham, Shahar, \& Widaman, 2002). In order to combine the items to parcels, we analyzed the scale on the basis of a confirmatory factor analysis. With respect to the factor loadings, we then allocated items to parcels ensuring that all parcels had equal characteristics. Career satisfaction had an average variance extracted of $65.2 \%$ and proactivity of $58.0 \%$. We considered job embeddedness as a heterogeneous construct and treated it as a formative measurement model (MacKenzie, Podsakoff, \& Jarvis, 2005). For this variable as well as for the mediators and the dependent variable which were all dichotomous, we used manifest variables in the structural model.

To cope with the dichotomous mediators and dependent variable, we conducted structural equation models based on probit instead of linear regressions (Muthén, 1984). Several advantages regarding the interpretation of results and the test of model fit have been identified for the probit regression using a WLSMV estimator (Agresti, 
2007). First, this type of analysis uses the underlying continuous latent responses as mediator and dependent variables instead of the observed ones. Thus, the variables can still be normal distributed in the population even if they have an observed non-symmetric distribution (Muthén, 2011). This procedure implies that the probit scores can be interpreted as linear probability coefficients when being mindful of the latent continuous response $\mathrm{y}^{\star}$ (Skrondal \& Rabe-Hesketh, 2005). $\mathrm{y}^{\star}$ can be thought of as the underlying latent propensity that the binary variable is occurring $(y=1)$. The marginal effect then describes the probability change of $\mathrm{y}^{\star}$ for each unit change of a predictor which is more intuitive than odds ratios. Second, an evaluation of model fit becomes possible using the robust WLMSV estimator in a probit regression with Mplus (Muthén, 1993). Additionally, the WLMSV estimator is recommended because of more precise and unbiased parameter solutions (Beauducel \& Herzberg, 2006).

All parameter estimates will be reported as fully standardized coefficients. Hence, $\beta$ coefficients, called standardized probit scores, describe the standard deviation increase in $\mathrm{y}^{\star}$ given a one standard deviation increase in a predictor holding all other variables constant (Agresti, 2007). Model fit was assessed using chi-square statistics. Furthermore, the following descriptive goodness-of-fit measures were used to evaluate the hypothesized model. We report the Root Mean Square Error of Approximation (RMSEA), which is recommended to be smaller than .05 indicating a good model fit (Browne \& Cudeck, 1993), and the Comparative Fit Index (CFI) as well as the Tucker-Lewis Index (TLI) as relative descriptive indices which should be higher than 97 (Schermelleh-Engel, Moosbrugger, \& Müller, 2003). Descriptive statistics and zero-order correlations among the variables are reported in Table 1 . As all hypotheses were directed, one-sided significance testing was used.

\section{Results}

The main results of our study are summarized in Figure 2 and Table 2. We first tested the fit of the research model (model 1, see Figure 1) based on our hypotheses 1 to 7 . The chi-square statistics showed a good model fit $\left(\chi^{2}=21.65, d f=20, p=.36\right)$. Moreover, all reported descriptive fit indices yielded excellent values $(R M S E A=.021 ; C F I=.994$;

Table 1. Means (M), standard deviations (SD), and correlations of variables.

\begin{tabular}{ccccccccc}
\hline & Variable & $M$ & $S D$ & 1 & 2 & 3 & 4 & 5 \\
\hline 1 & Proactivity & 3.87 & .48 & $(.81)$ & & & \\
2 & Career satisfaction & 3.60 & .70 & $.25^{* *}$ & $(.80)$ & & \\
3 & Job embeddedness & 3.12 & .46 & $.16^{*}$ & $.47^{* *}$ & $(.60)$ & \\
4 & Job opportunities & .60 & .49 & $.14^{*}$ & $.15^{*}$ & -.00 & & \\
5 & Job interviews & .34 & .47 & 16 & $-.15^{*}$ & $-.22^{* *}$ & $.34^{* *}$ & \\
6 & Turnover & .15 & .35 & .04 & -.02 & -.00 & $.18^{* *}$ & $.38^{* *}$ \\
\hline
\end{tabular}

Notes: $N=192$. Job Opportunities, Job Interviews and Turnover are coded as $0=$ no and $1=$ yes. Reliability estimates $(\alpha)$ are shown in parentheses on the diagonal. ${ }^{*} p<.05$; ${ }^{* *} p<.01$. 
Table 2. Model comparisons.

\begin{tabular}{cccccccc}
\hline Model & & $\chi^{2}$ & $d f$ & $p$ & $R M S E A$ & CFI & TLI \\
\hline 0 & Baseline model & 298.26 & 36 & .00 & & & \\
1 & Research model & 21.65 & 20 & .36 & .021 & .994 & .989 \\
2 & Research model adjusted & 22.39 & 21 & .38 & .019 & .995 & .991 \\
3 & Comparison model & 18.98 & 18 & .39 & .017 & .996 & .993 \\
\hline
\end{tabular}

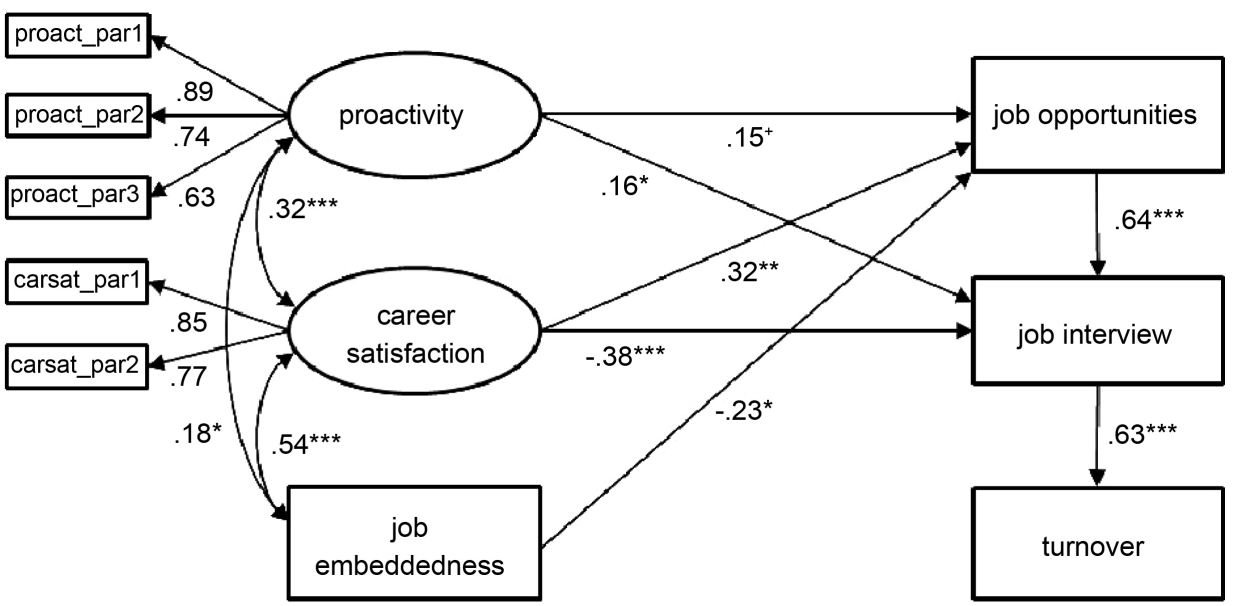

Figure 2. Structural equation model (adjusted research model 2) examining the assumed direct and indirect effects of proactivity, career satisfaction, job embeddedness, job opportunities, job interview and turnover.

$T L I=.989$ ). One of the hypothesized effects, however, was not significant (see below). We fixed this path to zero resulting in a slightly improved model $\left(\chi^{2}=22.39, d f=21\right.$, $p=.38 ; R M S E A=.019 ; C F I=.995 T L I=.991)$. The results reported in the following are based on this adjusted research model (model 2).

The relationship between proactivity and job opportunities was in the expected direction and was marginally significant $(\beta=.15, p<.10)$. Thus, hypothesis 1a found partial support. Furthermore, in line with hypothesis $1 \mathrm{~b}$, we found a significant positive effect of proactivity on going to job interviews $(\beta=.16, p<.05)$. Moreover, career satisfaction significantly predicted receiving alternative job opportunities $(\beta=.32, p<.01)$ which was, however, counter to our expectations, as we expected a negative relationship. Hypothesis $2 \mathrm{a}$ had to be rejected. However, in line with hypothesis $2 \mathrm{~b}$, career satisfaction showed a negative relationship with job interviews $(\beta=-.38, p<.001)$. More satisfied employees are less likely to go to job interviews. Moreover, data showed that higher embedded employees had a lower probability of receiving alternative job opportunities $(\beta=-.23, p<.05)$ which is in line with hypothesis $3 a$. Contrary to our assumption ( $\mathrm{H} 3 \mathrm{~b}$ ), however, job embeddedness was not negatively related to taking part in job interviews $(\beta=-.08, p>.10)$. We fixed this path to zero for the adjusted research model 2, which is presented in Figure 2.

As expected, job opportunities showed a very strong positive probit relationship to 
job interviews $(\beta=.64, p<.001)$ indicating that people having alternative opportunities tend to go to job interviews (H4a). Furthermore, going to job interviews increased the probability for turnover $(\beta=.63, p<.001)$ which was in support of hypothesis $4 \mathrm{~b}$. Next, we analyzed the indirect effects of all exogenous variables. In hypothesis 5 we assumed that in addition to the effects of proactivity ( $\mathrm{t} 1$ ) on receiving job opportunities ( $\mathrm{t} 2$ ) and going to job interviews ( $\mathrm{t} 2$ ) analyzed in hypotheses $1 \mathrm{a}$ and $\mathrm{b}$ there is an indirect effect on the probability of signing a new job contract (t2) six months later via these variables. The results indicated a moderately high positive indirect effect $(\beta=.16, p<.01)$, thus supporting hypothesis 5. Analyzing the respective indirect effects of career satisfaction, a negative coefficient revealed which just failed to reach significance $(\beta=-.11, p=.056)$. This marginally significant effect is a consequence of the fact that career satisfaction was positively related to job opportunities (which was positively related to job interviews), but it was negatively related to job interviews. That is, there was a negative indirect effect $(\beta=-.24, p<.05)$ career satisfaction-job opportunities-job interviewsturnover and a positive effect $(\beta=.13, p<.05)$ career satisfaction-job interviews-turnover. Nevertheless, there is a small negative effect on turnover in total, thus supporting hypothesis 6 partially. Finally, in support of hypothesis 7 , there was a significant negative indirect effect $(\beta=-.09, p<.05)$ of job embeddedness on turnover. Job embedded people have a lower probability of signing up a new contract six months later.

Finally, we analyzed whether there were direct effects of the exogenous variables proactivity, career satisfaction and embeddedness on turnover on top of the indirect effects (see Figure 1, the research model including the dotted lines). The chi square statistics (Table 2) showed that this competitive model (model 3) did not result in a better solution $\left(\Delta \chi^{2}=3.41 ; \Delta \mathrm{df}=3 ; \quad \chi_{\text {crit }}^{2}=7.81\right)$. Therefore, hypothesis 8 postulating a better fit of a model comprising both direct and indirect effects was rejected and the mediatedproactivity-career satisfaction-job embeddedness-turnover model assuming indirect effects only (model 2) found most support by the data.

\section{Discussion}

Organizational research often highlights the positive impact of proactivity on organizational and individual performance, but differs in its assumptions about voluntary turnover propensity (Morgan et al., 2012; Seibert et al., 2001; Swider et al., 2011). This study offers an alternative approach to examine the effect of proactivity on voluntary turnover within an employment context. Our model implies that voluntary turnover is a function of proactivity, on- and off-the-job forces like career satisfaction (Greenhaus et al., 1990), job embeddedness (Mitchell et al., 2001) and its impacts on job opportunities and going to job interviews. Our findings provide support for the proposed model. Each variable appears to play a different important role in a voluntary turnover process. Our model integrates findings reported in previous studies on turnover (Holtom et al., 2008) and offers new insights into how proactivity, career satisfaction, job embeddedness and perceived job alternatives work together and effect voluntary turnover.

In line with prior research (Seibert et al., 2001), our results support the idea that 
proactivity is related to the probability to receive more often alternative job opportunities, though the effect just fails to reach conventional levels of statistical significance (H1a). Furthermore, our findings support arguments (Briscoe et al., 2006) about a strong positive relationship between proactivity and the willingness to check job opportunities by accepting invitations to job interviews (H1b). Counter to our hypothesis, career satisfaction also attracts more alternative job opportunities, an important antecedent of voluntary turnover $(\mathrm{H} 2 \mathrm{a})$. One possible explanation for this unexpected finding may be that career satisfied individuals deliver convincing performance and present themselves as attractive talents and high achievers on the internal and external job market (Crant, 2000). Career networks like LinkedIn or Xing may take advantage of this supposed tendency of self-promotion and report a growing number of members, posting their resumes and core competencies (Ng et al., 2005). People who become more visible on career platforms as attractive work force may be probably more often contacted for open job opportunities, because both headhunters and employers increasingly actively search for suitable candidates for their vacancies in social media networks (SHRM Staffing Research, 2008). However, in line with most previous turnover research (Holtom et al., 2008), career satisfaction was also a strong argument not to go to job interviews and to seek for greener pastures elsewhere, which was in line with our hypothesis ( $\mathrm{H} 2 \mathrm{~b})$.

With respect to job embeddedness, our results are consistent with findings of Mitchell et al. (2001) in as job embedded people report significantly less job opportunities (H3a). Contrary to our expectation (H3b), job embeddedness has no significant effect on accepting invitations to job interviews. Our results therefore only partially confirm the role of job embeddedness in preventing turnover preparing behavior (Mitchell et al., 2001). Job and community embedded employees do not actively search new employment opportunities. Because of their embeddedness they may be also less active in job portals. And yet, despite of these beneficial hindering effects, it is quite astonishing that job embeddedness cannot predict whether employees will invest time and effort to go to job interviews. We need indeed more research on the embeddedness construct to enhance our understanding of how alternative job opportunities lying on the table will interfere with continuance intentions.

Our findings also correspond to March and Simon's (1958) two-factor model of turnover and the unfolding model approach (Lee \& Mitchell, 1994), both supposing that leaving for something better is sometimes triggered by attractive alternatives even without actual career dissatisfaction. Our results provide strong support for H4a proposing that job opportunities increase the probability to go to job interviews and for H4b suggesting that going to job interviews enhance the likelihood to sign a new job contract (H4b).

The data support a positive relationship between proactivity and voluntary turnover through the mediating effects of job opportunities and job interviews (H5). This finding offers a first indication why previous research on the relationship between proactivity and turnover fails to provide unambiguous results. Taking into account how proactivity 
works together with perceived job alternatives expands previous research examining effects of proactivity on leaving intentions (Morgan et al., 2012; Seibert et al., 2001) or job changes only (Boudreau et al., 2001). HR professionals have to keep in mind, that proactive employees are not per se more often leavers, but they will receive more often job opportunities through their marketability on the external job market. Their profound willingness to accept interview invitations will increase the probability to make a turnover decision.

For career satisfaction, we found two contradictory effects. As expected, career satisfaction prevented voluntary turnover through its direct effect on not going to job interviews, but increased voluntary turnover through its positive direct effect on alternative job opportunities and the strong positive relationship between alternative job opportunities, job interviews and voluntary turnover. The fact that career satisfied employees rejected a higher percentage of interview invitations was partly counterbalanced by the fact that they had more job opportunities. The total indirect effect is, however, still in favour of hypothesis 6 suggesting that career satisfied employees tend to remain in the organization and therefore in line with previous turnover research (Holtom et al., 2008). Even if our results indicate a small indirect positive effect of career satisfaction on staying and not leaving, it is probably wise to pay special attention to this side of career satisfaction in future voluntary turnover models. In line with prior research (Mitchell et al., 2001) we found a small positive indirect effect of job embeddedness preventing job changes (H7). As embedded employees tend to search less actively for alternative jobs and are therefore probably less visible on the job market, they will perceive also less often alternative job opportunities. A smaller number of perceived job opportunities entails lower rates of job invitations and reduces therefore the probability to get and accept an alternative job contract.

As mentioned earlier, previous research has often looked at direct effects of proactivity on turnover. The evaluation of a turnover model with both direct and indirect effects of all independent variables on turnover clearly showed that all effects of independent variables on turnover were indirect via job opportunities and job interviews. This can be expected because in most societies hiring companies want to meet and talk with potential new members of their organization (Wilhelmy, Kleinmann, König, Melchers, \& Truxillo, 2016). Therefore, offering a job opportunity and inviting somebody to a job interview is a necessary prerequisite for signing a new job contract. Therefore it should be little surprising that our data support a full mediation model.

\section{Limitations and Future Research}

Several limitations are important to consider in the context of interpreting the findings of the present study. As all data were assessed using self-report questionnaires, the possibility of a common method variance (CMV) arises (Podsakoff, MacKenzie, Lee, \& Podsakoff, 2003). CMV caused through items with similar wording and response formats, socially desirable responding, and transient factors like mood (Williams, Hartman, \& Cavazotte, 2010) should only play a minor role for anonymous online ques- 
tionnaires. For most employees receiving job opportunities, going to an interview and changing the job are salient events that should be remembered for at least six months. However we used a lagged design and effects of proactivity, career satisfaction and job embeddedness on the dependent variables seem highly plausible, the present design does not allow drawing causal conclusions as this would require the repeated measurement of both independent and dependent variables (Zapf, Dormann, \& Frese, 1996). However, the temporal separation of measures helped alleviating some of the method biases (Podsakoff et al., 2003; Zapf et al., 1996). Another limitation is the use of online surveys and the recruitment of participants via email. These context specific characteristics of our data collection may have had an impact on nonresponse and coverage errors and are difficult to influence (Alwin, 2007). Although our sample includes employees with various professions, different age and education-levels from a variety of organizations in Germany, its representativeness of the broader employee population cannot be ensured. Having carried out the present study in Germany is a strength-it replicates findings from Anglo-American countries-and a weakness at the same time. Indeed, we need further research replicating our study design in other countries and assessing our outcome measures from different sources.

\section{Implications for Practice}

Handling the dynamics of proactivity at work is challenging for HR professionals and executives. Proactive employees need sufficient freedom to unfold their specific qualities like innovativeness, creativity and extra-role performance. Nothing is as debilitating for proactive professionals as deadlocked structures and a stagnating career progress. To keep proactive individuals on board, organizations have to offer sufficient career options and prospering business models. In filling vacancies, we therefore recommend to consider carefully the potential fit between given or future job conditions and the specific mind-sets of proactive people (Grant, Parker, \& Collins, 2009). With regard to our study results, supporting a distinct positive relationship between proactivity and voluntary turnover, it is also worth mentioning that a growing number of proactive staff members will increase considerably the probability of losing some of them to competitors. In spite of the best efforts in matching job profiles to personality types, it might be also helpful to shape working teams as diverse as necessary.

\section{Conclusion}

In an effort to extend prior proactivity and turnover research, we proposed a study model that examined the impacts of proactivity on- and off-the-job forces like career satisfaction, job embeddedness and perceived job alternatives on voluntary turnover. Our findings provide first insights into the complex positive relationship between proactivity and voluntary turnover. Our results may contribute to future HRM research by offering a well-fitting proactivity-turnover model that may help to improve future organizational staffing and retention strategies. 


\section{References}

Agresti, A. (2007). Logistic Regression. An Introduction to Categorical Data Analysis (2nd ed., pp. 99-136). http://dx.doi.org/10.1002/9780470114759.ch5

Allen, D. G., Weeks, K. P., \& Moffitt, K. R. (2005). Turnover Intentions and Voluntary Turnover: The Moderating Roles of Self-Monitoring, Locus of Control, Proactive Personality, and Risk Aversion. Journal of Applied Psychology, 90, 980-990. http://dx.doi.org/10.1037/0021-9010.90.5.980

Alwin, D. F. (2007). Margins of Error: A Study of Reliability in Survey Measurement (Vol. 547). John Wiley \& Sons. http://dx.doi.org/10.1002/9780470146316

Bateman, T. S., \& Crant, J. M. (1993). The Proactive Component of Organizational Behavior: A Measure and Correlates. Journal of Organizational Behavior, 14, 103-118. http://dx.doi.org/10.1002/job.4030140202

Beauducel, A., \& Herzberg, P. Y. (2006). On the Performance of Maximum Likelihood Versus Means and Variance Adjusted Weighted Least Squares Estimation in CFA. Structural Equation Modeling, 13, 186-203. http://dx.doi.org/10.1207/s15328007sem1302_2

Boudreau, J. W., Boswell, W. R., Judge, T. A., \& Bretz, R. D. (2001). Personality and Cognitive Ability as Predictors of Job Search among Employed Managers. Personnel Psychology, 54, 2550. http://dx.doi.org/10.1111/j.1744-6570.2001.tb00084.x

Briscoe, J. P., Hall, D. T., \& DeMuth, R. L. F. (2006). Protean and Boundaryless Careers: An Empirical Exploration. Journal of Vocational Behavior, 69, 30-47. http://dx.doi.org/10.1016/j.jvb.2005.09.003

Browne, M. W., \& Cudeck, R. (1993). Alternative Ways of Assessing Model Fit. Sage Focus Editions, 154, 136-136.

Cosack, S., Guthridge, M., \& Lawson, E. (2010). Retaining Key Employees in Times of Change. McKinsey Quarterly, 3, 135-139.

Crant, J. M. (2000). Proactive Behavior in Organizations. Journal of Management, 26, 435-462. http://dx.doi.org/10.1177/014920630002600304

Crossley, C. D., Bennett, R. J., Jex, S. M., \& Burnfield, J. L. (2007). Development of a Global Measure of Job Embeddedness and Integration into a Traditional Model of Voluntary Turnover. Journal of Applied Psychology, 92, 1031-1042.

http://dx.doi.org/10.1037/0021-9010.92.4.1031

Dormann, C., \& Zapf, D. (2001). Job Satisfaction: A Meta-Analysis of Stabilities. Journal of Organizational Behavior, 22, 483-504. http://dx.doi.org/10.1002/job.98

Frese, M., \& Fay, D. (2001). Personal Initiative (PI): An Active Performance Concept for Work in the 21st Century. In B. M. Staw, \& R. M. Sutton (Eds.), Research in Organizational Behavior (Vol. 23, pp. 133-187). Amsterdam: Elsevier Science.

Fuller, B., \& Marler, L. E. (2009). Change Driven by Nature: A Meta-Analytic Review of the Proactive Personality Literature. Journal of Vocational Behavior, 75, 329-345. http://dx.doi.org/10.1016/j.jvb.2009.05.008

Glebbeek, A. C., \& Bax, E. H. (2004). Is High Employee Turnover Really Harmful? An Empirical Test Using Company Records. Academy of Management Journal, 47, 277-286. http://dx.doi.org/10.2307/20159578

Grant, A. M., \& Ashford, S. J. (2008). The Dynamics of Proactivity at Work. Research in Organizational Behavior, 28, 3-34. http://dx.doi.org/10.1016/j.riob.2008.04.002

Grant, A. M., Parker, S., \& Collins, C. (2009). Getting Credit for Proactive Behavior: Supervisor Reactions Depend on What You Value and How You Feel. Personnel Psychology, 62, 31-55. 
http://dx.doi.org/10.1111/j.1744-6570.2008.01128.x

Greenhaus, J. H., Parasuraman, S., \& Wormley, W. M. (1990). Effects of Race on Organizational Experiences, Job Performance Evaluations, and Career Outcomes. Academy of Management Journal, 33, 64-86. http://dx.doi.org/10.2307/256352

Griffeth, R. W., Hom, P. W., \& Gaertner, S. (2000). A Meta-Analysis of Antecedents and Correlates of Employee Turnover: Update, Moderator Tests, and Research Implications for the Next Millennium. Journal of Management, 26, 463-488. http://dx.doi.org/10.1177/014920630002600305

Griffin, M. A., Parker, S. K., \& Mason, C. M. (2010). Leader Vision and the Development of Adaptive and Proactive Performance: A Longitudinal Study. Journal of Applied Psychology, 95, 174. http://dx.doi.org/10.1037/a0017263

Hambleton, R. K., \& Kanjee, A. (1995). Increasing the Validity of Cross-Cultural Assessments: Use of Improved Methods for Test Adaptations. European Journal of Psychological Assessment, 11, 147-157. http://dx.doi.org/10.1027/1015-5759.11.3.147

Holtom, B. C., Mitchell, T. R., Lee, T. W., \& Eberly, M. B. (2008). 5 Turnover and Retention Research: A Glance at the Past, a Closer Review of the Present, and a Venture into the Future. The Academy of Management Annals, 2, 231-274. http://dx.doi.org/10.1080/19416520802211552

Lee, T. W., \& Mitchell, T. R. (1994). An Alternative Approach: The Unfolding Model of Voluntary Employee Turnover. Academy of Management Review, 19, 51-89.

Lewin, K. (1951). Field Theory in Social Science. New York: Harper.

Little, T. D., Cunningham, W. A., Shahar, G., \& Widaman, K. F. (2002). To Parcel or Not Toparcel: Exploring the Question, Weighing the Merits. Structural Equation Modeling, 9, 151-173. http://dx.doi.org/10.1207/S15328007SEM0902_1

MacKenzie, S. B., Podsakoff, P. M., \& Jarvis, C. B. (2005). The Problem of Measurement Model Misspecification in Behavioral and Organizational Research and Some Recommended Solutions. Journal of Applied Psychology, 90, 710-730.

http://dx.doi.org/10.1037/0021-9010.90.4.710

March, J. G., \& Simon, H. A. (1958). Organizations. New York: Wiley.

Michaels, E., Handfield-Jones, H., \& Axelrod, B. (2001). The War for Talent. Brighton, MA: Harvard Business Press.

Mitchell, T. R., Holtom, B. C., Lee, T. W., Sablynski, C. J., \& Erez, M. (2001). Why People Stay: Using Job Embeddedness to Predict Voluntary Turnover. Academy of Management Journal, 44, 1102-1121. http://dx.doi.org/10.2307/3069391

Morgan, W. B., Walker, S. S., Wang, Y., \& Aven Jr., F. F. (2012). Proactive and Committed: Characteristics for Retention. Journal of Organizational Psychology, 12, 97-108.

Morrison, E. W., \& Phelps, C. C. (1999). Taking Charge at Work: Extrarole Efforts to Initiate Workplace Change. Academy of Management Journal, 42, 403-419. http://dx.doi.org/10.2307/257011

Muthén, B. (1993). Goodness of Fit with Categorical and Other Non-Normal Variables. In K. A. Bollen, \& J. S. Long (Eds.), Testing Structural Equation Models (pp. 205-243). Newbury Park, CA: Sage Publications.

Muthén, B. (1984). A General Structural Equation Model with Dichotomous, Ordered Categorical, and Continuous Latent Variable Indicators. Psychometrika, 49, 115-132.

http://dx.doi.org/10.1007/BF02294210

Muthén, B. (2011). Applications of Causally Defined Direct and Indirect Effects in Mediation 
Analysis Using SEM in Mplus.

Muthén, L. K., \& Muthén, B. O. (1998-2012). Mplus User’s Guide.

Ng, T. W., Eby, L. T., Sorensen, K. L., \& Feldman, D. C. (2005). Predictors of Objective and Subjective Career Success: A Meta-Analysis. Personnel Psychology, 58, 367-408. http://dx.doi.org/10.1111/j.1744-6570.2005.00515.x

Parker, S. K., Williams, H. M., \& Turner, N. (2006). Modeling the Antecedents of Proactive Behavior at Work. Journal of Applied Psychology, 91, 636-652.

http://dx.doi.org/10.1037/0021-9010.91.3.636

Podsakoff, P. M., MacKenzie, S. B., Lee, J. Y., \& Podsakoff, N. P. (2003). Common Method Biases in Behavioral Research: A Critical Review of the Literature and Recommended Remedies. Journal of Applied Psychology, 88, 879-903. http://dx.doi.org/10.1037/0021-9010.88.5.879

Posthuma, R. A., Maertz, C. P., \& Dworkin, J. B. (2007). Procedural Justice's Relationship with Turnover: Explaining Past Inconsistent Findings. Journal of Organizational Behavior, 28, 381398. http://dx.doi.org/10.1002/job.427

Rynes, S. L., \& Cable, D. M. (2003). Recruitment Research in the Twenty-First Century. In W. C. Borman, D. R. Ilgen, \& R. J. Klimoski (Eds.), Handbook of Psychology (pp. 55-76). Hoboken, NJ: Wiley Publishing. http://dx.doi.org/10.1002/0471264385.wei1204

Schermelleh-Engel, K., Moosbrugger, H., \& Müller, H. (2003). Evaluating the Fit of Structural Equation Models: Tests of Significance and Descriptive Goodness-of-Fit Measures. Methods of Psychological Research Online, 8, 23-74.

Seibert, S. E., Kraimer, M. L., \& Crant, J. M. (2001). What Do Proactive People Do? A Longitudinal Model Linking Proactive Personality and Career Success. Personnel Psychology, 54, 845874. http://dx.doi.org/10.1111/j.1744-6570.2001.tb00234.x

SHRM Staffing Research (2008). Online Technologies and Their Impact on Recruitment Strategies. SHRM Staffing Research.

Skrondal, A., \& Rabe-Hesketh, S. (2005). Structural Equation Modeling: Categorical Variables. In B. S. Everitt, \& D. C. Howell (Eds.), Encyclopedia of Statistics in Behavioral Science (pp. 19051910). Chichester: John Wiley \& Sons Ltd. http://dx.doi.org/10.1002/0470013192.bsa596

Swider, B. W., Boswell, W. R., \& Zimmerman, R. D. (2011). Examining the Job Search-Turnover Relationship: The Role of Embeddedness, Job Satisfaction, and Available Alternatives. Journal of Applied Psychology, 96, 432-441. http://dx.doi.org/10.1037/a0021676

Tornau, K., \& Frese, M. (2013). Construct Clean-Up in Proactivity Research: A Meta-Analysis on the Nomological Net of Work-Related Proactivity Concepts and Their Incremental Validities. Applied Psychology, 62, 44-96. http://dx.doi.org/10.1111/j.1464-0597.2012.00514.x

Van Dyne, L., \& LePine, J. A. (1998). Helping and Voice Extra-Role Behaviors: Evidence of Construct and Predictive Validity. Academy of Management Journal, 41, 108-119.

http://dx.doi.org/10.2307/256902

Wilhelmy, A., Kleinmann, M., König, C. J., Melchers, K. G., \& Truxillo, D. M. (2016). How and Why Do Interviewers Try to Make Impressions on Applicants? A Qualitative Study. Journal of Applied Psychology, 101, 313-332. http://dx.doi.org/10.1037/apl0000046

Williams, L. J., Hartman, N., \& Cavazotte, F. (2010). Method Variance and Marker Variables: A Review and Comprehensive CFA Marker Technique. Organizational Research Methods, 13, 477-514. http://dx.doi.org/10.1177/1094428110366036

Zapf, D., Dormann, C., \& Frese, M. (1996). Longitudinal Studies in Organizational Stress Research: A Review of the Literature with Reference to Methodological Issues. Journal of Occupational Health Psychology, 1, 145-169. http://dx.doi.org/10.1037/1076-8998.1.2.145 
Submit or recommend next manuscript to SCIRP and we will provide best service for you:

Accepting pre-submission inquiries through Email, Facebook, LinkedIn, Twitter, etc. A wide selection of journals (inclusive of 9 subjects, more than 200 journals)

Providing 24-hour high-quality service

User-friendly online submission system

Fair and swift peer-review system

Efficient typesetting and proofreading procedure

Display of the result of downloads and visits, as well as the number of cited articles

Maximum dissemination of your research work

Submit your manuscript at: http://papersubmission.scirp.org/

Or contact psych@scirp.org 